\title{
TARI WOLEKA: SENI RITUAL MAGIS MASYARAKAT MARAPU DI SUMBA BARAT
}

\author{
S. Hudijono ${ }^{1}$
}

\begin{abstract}
This article aim to to study art of ritual magical which leave from social context of society culture of West Sumba which is is important to be [done/conducted] to see artistic attachment of ritual with his society. This dance have vitally function, especially for society which still embrace trust of Marapu. The function related to importance of ritual, where that related/relevant ritus is also named by party of woleka. Ritus it is a ceremony form to have an out, to blessing and of subsistence/livelihood to ancestor late.
\end{abstract}

Keywords: Woleka, ritus ceremony, and Sumba Barat.

Seni pertunjukan yang bersifat ritual magis bisa tetap hadir di tengah kehidupan masyarakat bila memiliki peran tertentu dalam kehidupan. Sebuah seni pertunjukan ritual yang dianggap mempunyai fungsi yang sangat penting dan berperan dalam kehidupan masyarakat, akan terus mendapat dukungan untuk bertahan hidup. Dengan demikian, keberadaan sebuah seni pertunjukan ritual akan tergantung kepada penerimaan masyarakat itu sendiri. Apabila masyarakat masih membutuhkan kehadirannya, maka kesenian itu akan dibina untuk ditumbuhkembangkan, tetapi sebaliknya, apabila masyarakat sudah tidak membutuhkan lagi, maka kesenian itu akan memudar atau lenyap. Sebagai sebuah seni pertunjukan, tari woleka memiliki fungsi yang berkaitan dengan kepentingan ritual masyarakat Sumba Barat Propinsi Nusa Tenggara Timur. Kehadiran tari woleka sebagai sebuah seni ritual

\footnotetext{
${ }^{1}$ S. Hudijono adalah Dosen Universitas Nusa Cendana Kupang
} 
dilatarbelakangi berbagai macam nilai-nilai kultural dalam masyarakat. Tulisan ini bertujuan untuk mengkaji seni ritual magis yang berangkat dari konteks sosial budaya masyarakat Sumba Barat yang penting dilakukan untuk melihat pertautan seni ritual dengan masyarakatnya.

Oleh penduduknya sendiri, pulau Sumba disebut Humba. Dalam Beding (2002: 18) disebutkan, Humba adalah isteri Umbu Manoku. Mereka dihayati masyarakat sebagai salah satu pasangan purba cikal bakal hidup dan kehidupan masyarakat Sumba. Sebagai tanda hormat dan cinta kepada isterinya, maka pulau yang diinjaknya pada saat pertama kali tiba di Sumba diabadikan dengan nama Humba. Dalam ucapan lokal orang Sumba, huruf $\mathrm{H}$ kerap kali berubah menjadi $\mathrm{Z}$ atau S, di mana Humba sering berubah menjadi Zumba atau Sumba. Lebih lanjut dijelaskan Gubernur Jenderal Kompeni Jan Maetsuyker pada tahun 1670 menyebut pulau Sumba sebagai "Siombo". Orang Barat menyebut pulau Sumba sebagai "Pulau Tsindana” atau "Sandel Bosch Eyland”. Orang Inggris menyebutnya sebagai "Sandelwood Island".

Salah satu tari tradisional di Sumba Barat adalah tari woleka (di Sumba Timur disebut goleka). Tari ini mempunyai fungsi yang amat penting, terutama bagi masyarakat yang masih menganut kepercayaan Marapu. Marapu adalah agama asli orang Sumba, yang di kabupaten Sumba Barat penganutnya tercatatat 97.635 jiwa, yang merupakan 27,77\% dari jumlah penduduk yang berjumlah 350.706 jiwa (Sumba Barat dalam Angka, 2004). Dalam Sumba Barat dalam Angka 2004, Marapu tidak disebutkan secara tegas sebagai kelompok agama (hanya disebut sebagai agama "lainnya") di samping kelompok-kelompok agama Protestan (43,92\%), Katholik (25,88\%), Islam (2,33\%), Hindu (0,09\%) dan Budha (0,025\%). Namun semua orang tahu, bahwa yang dimaksud "lainnya” itu adalah Marapu. Fungsi tersebut terkait dengan kepentingan ritual, di mana ritus terkait itu juga dinamakan pesta woleka. Secara harfiah, woleka berarti memukul gong, yang merupakan pertanda dimulainya ritus adat yang biasanya berlangsung selama tujuh hari tujuh malam. Ritus tersebut adalah suatu bentuk upacara untuk meminta ampun, berkat dan rezeki kepada arwah leluhur. Masyarakat setempat menyebut ritus tersebut sebagai 'pesta', karena begitu dominannya unsur 'makan bersama'. Ini sesuai dengan apa yang dikatakan Koentjaraningrat (1992: 262-263), yang menyatakan bahwa selain bersaji, berkorban, berdoa, menari/menyanyi, berprosesi dan lain-lain, maka 'makan bersama' merupakan perbuatan yang sangat penting dalam upacara 
banyak religi dan agama di dunia. Kelakuan keagamaan yang dilaksanakan menurut tata kelakuan yang baku disebut upacara keagamaan atau religious ceremonies atau rites.

Dasar pikiran di belakang perbuatan itu rupa-rupanya mencari hubungan dengan dewa-dewa (Marapu) dengan cara mengundang dewadewa tersebut dalam suatu pertemuan menari dan makan bersama. Marapu adalah suatu istilah yang ditujukan kepada Sang Dewata, yang dipercayai oleh orang Sumba sebagai pengantara antara manusia dengan Al-Khalik (dalam kehidupan sehari-hari, sinkretisme masih nampak jelas dijalankan oleh penduduk Sumba Barat walau telah menganut agama-agama baru). Wellem (2004: 42) mengatakan, Marapu adalah kepercayaan terhadap Dewa atau Ilah yang tertinggi, arwah nenek moyang, makhluk-makhluk halus (roh-roh) dan kekuatan-kekuatan sakti. Mereka dapat memberi berkat, perlindungan, pertolongan yang baik jika disembah. Jika tidak, mereka akan memberikan malapetaka atas manusia. Sedangkan Kapita (1976a: 9) menyebutkan, bahwa Marapu adalah leluhur yang didewakan. Menurut keyakinan orang Sumba, susunan masyarakat itu telah diterima oleh leluhur dan Alkhalik sendiri. Nama Alkhalik itu disebutnya dengan berbagai ungkapan: "na Mawulu Tau na Majii Tau” (yang menciptakan dan yang membuat manusia); lagi disebutnya: "Ina Pakawurungu - Ama Pakaruwungu" (Ibu semesta dan Bapak semesta); dan "Pandanyura Ngara - Pandapeka Tamu” (Yang tak diucapkan gelar dan yang tak disebutkan nama). Selanjutnya Kapita (1976b: 362) menjelaskan, Marapu adalah "umbu” (nenek moyang, leluhur) yang berasal dari langit atau dari seberang, ataupun yang lahir mula-mula sampai di Sumba, dikatakan: "ghida angggoupa patekina Magholo - Marawi, mala ba nggaba lendeduzi ghida” (mereka yang mendapat firman Alkhalik, jadi apabila ada kehendak/keinginan kita, kita landaskan/tujukan kepada mereka untuk menyampaikan kepada Alkhalik, ya oleh karena mereka adalah seolah-olah jembatan/perantara).

Pada masyarakat Sumba Barat, apalagi yang masih memeluk kepercayaan aslinya, tidak ada satu kehidupan yang tidak diliputi oleh rasa keagamaan. Pelaksanaannya dalam bentuk upacara, yang menurut Levi Strauss (1997: 159) merupakan kegiatan yang stereotip yang mencakup gerak isyarat, ucapan-ucapan dan obyek dan dilakukan di suatu tempat. Upacara mencerminkan kepercayaan masyarakat akan kehadiran aktif wujud-wujud dan kekuatan adikodrati, bertujuan 
mempengaruhi wujud, kekuatan dan roh, supaya tujuan dan kepentingan pelaku ritus terpenuhi. Upacara merupakan unsur pokok agama, yaitu agama 'in actu'. Upacara adat yang paling besar bila disbanding dengan upacara-upacara adat yang lain bagi masyarakat Marapu di Sumba Barat adalah 'pesta' woleka. Pesta woleka yang diadakan di desa Umbu Ngedo kecamatan Kodi Bangedo tahun 2001 menghabiskan tak kurang dari 100 ekor kerbau, 100 ekor sapi, 200 ekor babi dan beberapa ekor kuda (Kompas, 28 Mei 2002).

Penganut kepercayaan Marapu mengatakan bahwa pesta woleka tidak sembarang diadakan oleh manusia. Pesta woleka diadakan karena sebelumnya telah ada perjanjian antara manusia yang masih hidup dengan Marapu (arwah-arwah leluhurnya), sebagai akibat dari adanya suatu masalah yang terjadi dalam kehidupan manusia, seperti sakit yang berkepanjangan, gila, perempuan-perempuan meninggal pada saat melahirkan, kemarau panjang, bencana alam, dan masalah-masalah lainya yang sangat berdampak negatif dalam kehidupan manusia.

\section{TARI WOLEKA: BAGIAN DARI SEBUAH 'PESTA' ADAT}

Tari woleka adalah sebuah tari tradisionil. Hal ini mengacu pada Astuti (2004: 45) yang berpendapat bahwa tari tradisional adalah tari yang tumbuh dan terbentuk di dalam suatu komunitas dengan sistem nilai tradisional yang diacu secara mantap oleh warganya. Dalam tradisi Sumba Barat tidak ada satu segi kehidupan yang tidak diliputi oleh rasa keagamaan. Setiap keinginan manusia disampaikan melalui berbagai upacara persembahan dengan sesajian (hungu maraku) kepada Tuhan dengan perantaraan Marapu. Jenis sesajian berupa sirih pinang (papaha), kepingan emas dan perak (kawadaku), beras dan hewan ternak (Hadikusuna, 1993: 47). Karena begitu banyak hewan korban yang dibantai untuk upacara tersebut, tak urung kegiatan itu sering menuai kritik, di mana upacara tersebut merupakan suatu pemborosan yang luar biasa. Banyak pihak mensinyalir, bahwa kekurangan gizi sebagian masyarakat Sumba Barat antara lain disebabkan penyelenggaraan ritusritus tertentu dalam komunitas masyarakat Sumba Barat yang mengorbankan puluhan hingga ratusan hewan besar yang kadang-kadang hanya bersifat adu gengsi. Levi-Strauss (1997: 152) menggunakan istilah "potlatch" untuk kegiatan seperti itu, yang merupakan suatu pesta adat 
yang dimeriahkan dengan berbagai pameran harta kekayaan sebagai tanda kebanggaan. Kemudian, harta tersebut dibagikan atau dirusak untuk menantang dan menghina lawan atau memaksanya untuk membalas melampaui "hadiah" harta kekayaan tadi. Konsumsi protein hewani hanya terkonsentrasi dalam event seperti ini. Di luar itu, dalam rentang waktu yang panjang hewan-hewan besar jarang dipotong, sehingga mengurangi in-take protein, karena hewan-hewan besar tersebut dipersiapkan untuk menyambut upacara berikutnya.

Dalam alam pikiran orang Sumba Barat, woleka merupakan kebanggaan mereka (tenar / termashur), sebab menjadi kisah cerita orang banyak karena telah membunuh banyak hewan lebih dari orang lain yang telah pernah melaksanakan pesta yang sama. Berdasarkan pemahaman di atas, bila dikaitkan dengan bahasa Sumba, selain berarti memukul gong, secara etimologis woleka adalah "pesta pora”, karena membunuh banyak hewan, adanya makan bersama secara massif, bahkan membawa pulang dalam jumlah besar daging baik yang telah dimasak maupun yang masih mentah dan terkadang juga nasi. Istilah menyembelih hewan nyaris tak pernah dipergunakan di tanah Sumba, sebab pada kenyataannya hewan-hewan besar seperti kerbau penyembelihannya dilakukan dengan cara ditebas lehernya (teba karambo), sedang hewan kecil seperti babi dibunuh dengan cara ditusuk tepat di arah jantungnya.

Banyaknya hewan yang dikorbankan pada pesta woleka, merupakan suatu kebanggan yang sangat khusus bagi Tuan Pesta (penyelenggara pesta). Mereka yang hadir yang turut menyaksikan acara pembantaian hewan akan membawa cerita setelah sampai ke rumah masing-masing. Gema ceritanya akan bergaung sampai bertahun-tahun. Dengan banyaknya hewan yang dikorbankan, jelas bahwa darah dari setiap binatang tertumpah membasahi bumi, dan membanjiri halaman parona (kampung) tersebut. "Tanah berdarah/Banjir darah”, bagi masyarakat Sumba itu bermakna menolak bala dan menyuburkan tanah. Tuan Pesta ini akan disebut "Rato" (kaya).

Ritus adat seperti halnya 'pesta' Woleka adalah kekayaan masyarakat Sumba Barat. Meskipun penduduknya kebanyakan belum berkecukupan, atas dasar kepercayaan terhadap warisan leluhur, penyelenggaraan pesta adat selalu berlangsung tanpa hambatan berarti. Ritus adat, yang oleh masyarakat setempat disebut dengan 'pesta' adat yang memakan korban lebih dari seratus ekor hewan besar adalah salah 
satu bukti ketaatan mereka kepada arwah nenek moyang (Marapu). Demi ketaatan mereka kepada Marapu, mereka mengorbankan sejumlah besar kekayaan orang Sumba: ternak! 'Pesta' woleka juga suatu bukti bahwa miskin tidak berarti tidak ada pesta.

Tujuan pesta woleka tergantung perjanjian antara penyelenggara pesta dengan Marapu. Misalnya sebuah keluarga penganut kepercayaan Marapu ada yang sakit berkepanjangan dan setelah dicari penyebabnya, diketahui ada kelalaian dari keluarga tersebut dalam menjalani ketentuan Marapu, maka keluarga tersebut akan berjanji melalui sebuah upacara adat kecil yang dikenal dengan istilah "Urata". Urata adalah sebuah sebuah upacara religi yang dilakukan di dalam rumah oleh masyarakat setempat untuk menanyakan kepada Marapu, kesalahan apa yang diperbuat oleh keluarga tersebut. Jika sudah diketahui, keluarga tersebut akan berjanji dengan Marapu, untuk mengadalan pesta woleka untuk memohon pengampunan atau keselamatan dari Marapu. Dikatakan tergantung kepada perjanjian antara manusia dengan Marapu, karena pesta woleka ini diadakan dengan beragam tujuan, seperti terhindar atau sembuh dari penyakit yang mereka derita; terhindar dari gangguan jiwa (gila); terhindar dari kecelakaan, bencana alam, jatuh dari pohon, digigit binatang berbisa, mati mendadak, mati waktu melahirkan dan sebagainya; ternak maupun tanaman terhindar dari penyakit; ternak dan sawah ladang memberi hasil yang berlebih; menyampaikan rasa syukur atas keberhasilan yang telah dicapai; rumah tangga dan keluarga tetap dalam keadaan rukun, aman dan sejahtera dan terhindar dari perselisihan dengan keluarga inti maupun keluarga luas.

Inti dari pesta woleka adalah makan bersama, berprosesi, berdoa, menari (yang diringi dengan nyanyian). Makan bersama adalah aktivitas yang amat penting bagi masyarakat Sumba Barat, termasuk dengan arwah nenek moyang. Makanan yang disantap oleh manusia sama dengan yang disajikan kepada arwah nenek moyang. Tujuannya adalah untuk mempererat kohesi sosial. Kebiasaan turun-temurun pada masyarakat Sumba Barat, yang disantap bersama hanyalah nasi ditemani daging yang direbus dengan air dan garam saja. Jadi makan bersama dalam pesta woleka berbeda dengan makan bersama dalam pesta pernikahan misalnya. Dalam pesta pernikahan, para tamu mengambil sendiri (prasmanan), tetapi pada pesta woleka makanan diambilkan oleh para ibu yang bertugas memasak, dan jumlahnya tidak ada perbedaan antara anak-anak dan orang dewasa. Tanpa bermaksud melebih-lebihkan, tetapi 
ini adalah budaya orang Sumba Barat umumnya, nasi dan daging yang disuguhkan dalam jumlah yang banyak sekali. Demikian pula kalau daging ayam yang disuguhkan, setiap tamu yang datang akan disuguhi satu ekor ayam yang sudah dimasak, hanya "jeroannya" saja yang dikeluarkan.

Tempik sorak dan kegirangan, mengiringi prosesi yang dilakukan oleh orang-orang yang ambil bagian dalam pesta woleka, sambil membawa kerbau, sapi, babi, ayam dan lain-lain. Mereka yang membawa binatang-binatang tersebut bertempik sorak kegirangan bukan untuk mengusir roh jahat, tetapi ingin menunjukkan bahwa mereka juga mendukung keluarga yang menyelenggarakan pesta. Di lain pihak orang-orang yang berprosesi ini bermaksud memanggil arwah anggota keluarga yang dianggap masih bergentayangan di tempat yang tidak semestinya, karena meninggal dengan cara yang kurang wajar. Misalnya arwah saudaranya itu meninggal karena kecelakaan, bunuh diri atau dibunuh orang. Dengan membawa tambur, gendang dan gong serta bunyi-bunyian yang lain, mereka mengadakan upacara di tempat tersebut untuk memanggil arwah.

Berdoa adalah kegiatan memuja Marapu atau arwah nenek moyang dengan melantunkan syair-syair adat. Tujuannya adalah memohon agar arwah nenek moyang menjauhkan dari segala sakit kepada anak cucu dan hewan ternak peliharaan, serta panen yang berlimpah. Syair pemujaan yang selalu diucapkan adalah:

Inya kalada nganda, mono Ama mandeke Lii

Tilu rengngi mono, pote katanga gama Lii

Gaika ghou Inya mono Ama papboto papoza ma

Psili gama wira, tengge, mono klawara

Psili gama kapore wawi, manu, mono apa-apa

Yenggama, we susu, we baba

(Nguti pare mono apik watara)

Mama mulut besar, Bapa suara besar

Telingamu yang mendengarkan seruan kami

Supaya Engkau Mama dan Bapa yang puja dan sembah

Jauhkan kami dari batuk pilek dan demam bagi anak cucumu

Jauhkan berbagai penyakit ternak

Dan berilah kepada kami susu dan madu yang berlimpah

(Yakni panen padi dan jagung) 
Tari Woleka: Seni Ritual Magis ... (S. Hudijono)

\section{PEMENTASAN TARI WOLEKA}

Hingga saat ini masyarakat Sumba Barat masih menyelenggarakan pagelaran pertunjukan tari woleka (yang diiringi dengan nyanyian). Pelaksanaan dilakukan di halaman rumah adat (uma kalada) yang berupa rumah besar bermenara tinggi seperti bentuk rumah joglo di Jawa Tengah. Uma kalada adalah rumah milik bersama dari satu kabihu (marga). Tari woleka yang merupakan bagian inti dari pesta woleka, tidak bisa ditentukan secara reguler saatnya. Namun biasanya bagi keluarga yang mampu dilakukan 5 (lima) tahun sekali. Pelaksanaannya biasanya dilakukan pada bulan Juni atau Juli, dengan pertimbangan hujan sudah tidak lagi turun. Selain itu, pada bulan-bulan tersebut masyarakat Sumba Barat baru saja memanen hasil buminya yang berupa jagung, padi dan kopi.

Pada pelaksanaannya, penari woleka bukan terdiri dari orangorang yang pandai menari, tetapi siapa saja yang berminat bisa ikut tampil dalam pertunjukan tersebut. Begitu pula para pendukungnya tidak begitu mementingkan nilai-nilai artistik yang tinggi dari gerakan yang dimunculkan. Tindakannya lebih disadari adanya dorongan yang menyangkut kepercayaan, perayaan adat, memohon berkah dari Marapu, dan yang dipentingkan adalah tujuannya. Penari inti dibawakan oleh 2 (dua) pasangan penari (perempuan dan laki-laki), yang kesemuanya mengenakan pakaian adat dengan giring-giring di kaki. Penari-penari tersebut harus para penganut Marapu, dan diusahakan anak atau isteri dari Tuan Pesta terlibat di dalamnya. Pasangan-pasangan lain mengikuti penari inti, di mana penari laki-laki menari berkeliling sampil menghunus parang, yang merupakan lambang kejantanan laki-laki Sumba. Parang ini parang sungguhan, yang bagian tajamnya mempunyai panjang sekitar $50 \mathrm{~cm}$. Di luar penari inti, siapa saja yang merasa "berkeahlian” dan tidak berkeberatan, boleh ikut menari. Tari-tarian ini kebanyakan dilaksanakan malam hari hingga menjelang fajar dan berlangsung sampai seminggu. Dipercaya bahwa waktu pelaksanaan yang demikian dianggap tepat untuk berkomunikasi dengan Marapu. Tari woleka dalam ritus adat penganut Marapu tersebut memainkan peran penting sebagai bagian pesta adat yang menjembatani hubungan antara alam nyata dengan alam gaib. Teko toi (parang pusaka) 
Iringan tari woleka menggunakan instrumen bunyi yang di dalam unitnya terdiri dari gong besar kecil, kendang, tambur dan bedug. Antara tari dengan instrumen memiliki hubungan yang koheren. Dengan bunyi kendang, gong, bedug, dan tambur sambil bergoyang, penari melompat sambil menghentakkan kaki (kegiatan-kegiatan ini dalam bahasa aslinya dinamakan ndandu) di arena/halaman rumah. Kekuatan ekspresi tari Woleka banyak dibantu instrumen bunyi yang terpadu dari unsur-unsur melodi dan tempo, ritme/irama, dan volume yang khas. Gong lazimnya berjumlah enam buah, terdiri dari dua buah gong besar dan empat buah gong kecil. Jika dalam suatu pagelaran tari terdapat 5 (lima) gong kecil, maka gong yang ke-lima tersebut adalah penanda yang khas dari suatu kabihu (marga).

Kendang yang dipakai terdiri atas satu bidang pukul, yang pemakaiannya digantungkan di pundak penabuhnya dengan tali. Alat ini dianggap memiliki kekuatan tertentu dan suaranya dapat berpengaruh pada kehidupan manusia, sehingga kendang menjadi kebutuhan primer bagi manusia dalam melakukan upacara ritual. Bahan terbuat dari kayu berbentuk tabung ditutup dengan selaput kulit binatang yang diregangkan pada sisi bidang pukul sebagai sumber bunyi. Instrumen-instrumen tersebut merupakan modal dasar suara yang dituntut mampu menerjemahkan maksud tertentu melalui ekspresi musikalnya. Dari perpekstif pementasan terdapat juga unsur estetika yang mampu menumbuhkan sentuhan emosional. Unsur tersebut antara lain, penataan instrumen, hiasan instrumen, sikap musisi saat membawakan gending tertentu, dan tata teknik pertunjukan.

\section{SIMPULAN}

Woleka berfungsi untuk mempertebal rasa solidaritas kelompok. Solidaristas. yang dimaksud disini adalah solidaritas sesama penari, dan antar penari dengan penyelenggara pesta maupun dengan orang-orang yang terlibat di dalamnya. Melalui pertunjukan tari woleka, masyarakat terutama orang-orang yang terikat tali kekerabatan dengan penyelenggara pesta, berkumpul untuk bersama-sama berperan, mengemban tugas dan menunjukkan tanggung jawab masing-masing terhadap Marapu (arwah nenek moyang) yang dipercaya dapat melindungi mereka. 
Tari Woleka: Seni Ritual Magis ... (S. Hudijono)

\section{DAFTAR RUJUKAN}

Astuti, Budi. 2004, “Pembentukan Gaya Tari Gambyong Banyumasan”, dalam Jurnal Ekspresi Volume 10 tahun 4, Yogyakarta: Institut Seni Indonesia.

Badan Pusat Statistik Kabupaten Sumba Barat. 2005, Sumba Barat dalam Angka 2004.

Beding, B Michael \& Beding, S. Indah Lestari. 2002, Mozaik Sumba Barat, Waikabubak: Pemda Kabupaten Sumba Barat.

Hadikusuma, H. Hilman. 1993, Antropologi Agama Bagaian I: Pendekatan Budaya Terhadap Aliran Kepercayaan, Agama Hindu, Agama Budha, Kong $\mathrm{Hu} \mathrm{Cu}$, di Indonesia, Bandung: Penerbit P.T. Aditya Bakti.

Kapita, Oe. H. 1976a, Masyarakat Sumba dan Adat Istiadatnya, Waingapu: Panitia Penerbit Naskah-naskah Kebudayaan Daerah Sumba Dewan Penata Layanan Gereja Kristen Sumba. . 1976b, Sumba di dalam Jangkauan Jaman, Waingapu: Panitia Penerbit Naskah-naskah Kebudayaan Daerah Sumba Dewan Penata Layanan Gereja Kristen Sumba.

Koentjaraningrat. 1992, Beberapa Pokok Antropologi Sosial, Jakarta: Dian Rakyat.

Kompas. 28 Mei 2002, “Otonomi Kabupaten Sumba Barat”.

Levi-Strauss, Claude. 1997, Mitos, Dukun dan Sihir, Terjemahan Agus Cremers dan De Santo Johanes, Yogyakarta: Kanisius.

Tunggul, Nggodu. 2004, Etika dan Moralitas dalam Budaya Sumba, Jakarta: Pro Millenio Center.

Wellem, F.D. 2004, Injil dan Marapu: Suatu Studi Historis-Teologis tentang Perjumpaan Injil dengan Masyarakat Sumba pada Periode 1876-1990, Jakarta: BPK Gunung Mulia.

\section{Nara Sumber}

Pati Tondo, 45 tahun, Pemuka Adat desa Bukambero Kecamatan Kodi Kabupaten Sumba Barat.

Carolina Biri dan Oktavianus Bili, keduanya alumnus FKIP Universitas Nusa Cendana Kupang. 